E3S Web of Conferences 2, 02006 (2014)

DOI: $10.1051 / \mathrm{e} 3$ sconf/ 20140202006

(C) Owned by the authors, published by EDP Sciences, 2014

\title{
Global warming and water sustainability
}

\author{
Claudio Cassardo ${ }^{1,2,3}$ \\ ${ }^{1}$ Department of Physics, "Alma Universitas Taurinorum", Torino, Italy \\ ${ }^{2}$ CINFAI, National Inter/University Consortium for Physics of the Atmosphere and Hydrosphere, \\ Torino, Italy \\ ${ }^{3}$ NatRisk center, University of Torino "Alma Universitas Taurinorum”, Torino, Italy
}

\begin{abstract}
Water is a primary element in the human diet and a necessary resource for the agriculture. In addition, industrial practices need a growing amount of water. Since human population is continuously growing at a quasi-exponential rate, water demand, for domestic, agricultural and industrial uses, is increasing too. However, considering that the water resources on the Earth are finite, even disregarding the potential threats due to the climate change, this situation appears as one of the biggest challenges of the current era. Actually, one-third of the world's population is water-stressed, of which $12 \%$ severely: in these nations, a large portion of the population lives below the minimum threshold judged permissible for a decent life. In practice, almost every nation deals with problems related to water sustainability. In some countries, the water supply is ensured only thanks to the extraction of fossil water, which is a limited resource that will not last indefinitely. The impact on water quality has also dramatically increased. The scarcity of water resources is expected to spread to wider areas in the near future, mostly in developing countries, if the actual trends of development and population growth do not change. The rapid urbanizing rate will also create additional stress. Climate change can in turn alter both water supply and demand: increasing temperatures will reflect in increased evaporation and decreased stream flows. Rising seas could contaminate groundwater resources, and increasingly variable precipitation will likely mean more frequent high-intensity droughts and floods and less available rainfall in arid and semiarid regions. The effects of these changes will increase the natural variability of the climate, exacerbating the extreme climatic phenomena (drought and flood events), increasing the difficulty of managing water resources, especially in the most vulnerable regions, and affecting water availability even in regions that are not usually subjected to water shortage.
\end{abstract}

\section{Actual Earth Water Resources and Distribution}

The total water available on the planet amounts to 1,386 million cubic kilometers [1]. Most of human water uses (agricultural, industrial, household, recreational and environmental activities) require fresh water. $97 \%$ of water on Earth is salty, leaving only $3 \%$ as fresh water, of which slightly over two thirds (68.9\%) is frozen in glaciers and polar ice caps [2]. The remaining unfrozen fresh water is mainly found as groundwater (29.9\%), with only a small fraction present above ground $(0.3 \%)$ or in the air. For example, rivers account for the $0.0002 \%$ of total water, or $0.006 \%$ of fresh water, i.e., around 2,120 cubic kilometers. The above figures represent the potential reservoir of 
Earth's fresh water, and can be considered almost constant at the global scale and at the time scales of human existence.

Humans use mainly fresh surface water, and partially groundwater (more difficult to extract). A recent estimate [3] shows that $69 \%$ of worldwide water use is for agriculture (of which irrigation accounts for $65 \%$ [4]), $22 \%$ for industries, $1 \%$ for recreational purpose and $8 \%$ for household purposes (drinking water, bathing, cooking, sanitation, and gardening).

Moving from global to local scale, two points must be taken into consideration. First, the rapid population growth and increased water consumption are rapidly depleting the availability of water per capita: for instance, Hinrichsen (1998) [5] evaluated that, between 1960 and 1997, the per capita availability of freshwater worldwide declined by about $60 \%$. Second, the water resources are unevenly distributed in the world. The World Business Council for Sustainable Development [4] estimated that the minimum amount of water required per capita for food is about 400,000 liters per year, but in several developed nations it is quite higher (for instance, in the US, it is about four times larger: 1.7 million liters per capita per year [6]).

Despite the total amount of water available globally is sufficient to provide the world population with adequate fresh water, most of the total water is concentrated in specific regions, while other areas are water-deficient. In nearly 80 nations, the demands exceed the supplies [7]. These problems will intensify in the near future, due to the continuous population increase and climate change.

According to the Comprehensive Assessment of Water Management in Agriculture [8], the regions with water scarcity (which are not necessarily scarce in water resources) can be partitioned into three groups, according with their percentage of river flows withdrawn for agriculture, industry, and domestic purposes: (1) places in which the water resources development is approaching or has exceeded sustainable limits (more than 75\%); (2) places nearing physical water scarcity (more than $60 \%$ ); (3) places with economic water scarcity: in these places, human, institutional, and financial capital limit access to water even though water in nature is available locally to meet human demands (less than 25\%).

Water resources depletion and pollution are the major threats to maintain fresh water supplies for the increasing needs of the rapidly growing human population. Both affect surface water as well as groundwater resources. Pollution can dramatically limit the water quality, especially in developing countries, where approximately $95 \%$ of their untreated urban sewage is discharged directly into surface waters [9], but also in some well-developed nations [10]. Human wastes, pesticides, fertilizers, soil sediments eroded by rainfall, and untreated toxic chemicals from industry are among the greatest sources of pollutants [11], and can make the water unsuitable for human drinking and for irrigation [12].

At the beginning of the new millennium, the United Nations World Water Development Reports (WWDR), released every three years in conjunction with the World Water Forum since 2003, constitute a comprehensive review of the state of the world's freshwater resources. Specifically, the first edition of the World Water Development Report 1 [13] included some pilot case studies, and others were added in the following reports, that highlighted the basic issues and problems in achieving integrated approaches to water management, in order to enable the integration of the different elements on a local scale and reality into a coherent whole. Such cases, identifying the areas of greatest stress and pointing out the gaps in knowledge and understanding, were thus a kind of laboratory for testing methodologies and for evaluating lessons learned from examples of real-world practices.

\section{Short Term Prospects}

Technology is usually welcomed by many policy makers and public as a possible panacea to alleviate water resources problems. However, even though more efficient use and an improved environmental management of water resources can allow the same resources to serve a greater portion of the population, this is not a general solution. In fact, on the one hand, the developing countries are unable to support the high equipment and installation costs of more efficient technologies. On the 
other hand, science and technology also have some physical and economic limitations. Since the world population is expected to continue increasing at a rate not substantially different from the present one (according with the United Nations Environment Programme [14]), this will increase the per capita water demand. For instance, Jones [15] showed that water consumption increased by nearly $20 \%$ in the last two decades of the 20th century, and a further $20 \%$ expansion in the area of irrigated agriculture is still regarded as environmentally feasible.

Considering that, in several nations, the local management of the water resources is already not sustainable now, the prospects for the near future cannot be other than a matter for great concern. This consideration is even more valid for places where water resources are largely based on fossil water, extracted from deep groundwater reservoirs that are not being replenished in the current climate, as in most countries in the Middle East and North Africa. Even without considering the threat of the climate change (which is the object of the next section), it is evident that the above mentioned practices are a sort of palliative remedial act that does not solve the water resources problem at its root. Moreover, most of the population increment will occur in the lesser-developed countries, which are generally also more prone to water shortage. As a result, the assessment of global freshwater resources [16] calculated that, whereas a third of the world's population currently lives in countries suffering moderate to high water stress, by 2025 this will have risen to two thirds of a much larger population.

\section{The Challenge of Climate Change on Water Resources}

Unfortunately for humanity, climate change is not a distant possibility, but is already occurring. The IPCC (Intergovernmental Panel on Climate Change) AR4 [17], which represents the most comprehensive international scientific assessment ever conducted, concludes: "Warming of the climate system is unequivocal, as is now evident from observations of increases in global average air and ocean temperatures, widespread melting of snow and ice, and rising global average sea level". The evidence of global warming over the last two centuries is now overwhelming. There is also broad agreement amongst all the major Global Climate Models that the warming is likely to continue over the coming century so long as the concentration of greenhouse gases in the atmosphere continues to rise. The warming is expected to be highest in winter and at high elevations and latitudes. The summary for policy makers of the 5th Assessment Report of IPCC, published at the end of September 2013 , confirms that also the most recent studies agree on these results.

Global water resources are highly sensitive to temperatures, not only through the obvious effects of evaporation, but also because of the effects on wind patterns, convection and rainfall distribution [18]. The rainfall predictions are subject to the highest degree of imprecision, due to the intrinsic local variability of this variable. However, the results of the simulations recently carried out using regional climate models show that Mediterranean Europe is expected to experience drier summers than at present, while the northern and central Europe will experience an increase in severe rainfall events $[19,20]$. Also other results obtained in the frame of the projects CMIP3 and CMIP5 [21, 22], whose data constitute a scientific basis of the new IPCC Assessment Report, confirm the findings that several world sub-regions will experience altered hydrological regimes.

Since the climate system is not linear, even an increase in precipitation does not directly cause an increment in the water availability. For instance, in case of a contemporary temperature increase, evaporation will increase too, limiting, and in some cases actually reducing, the water availability. Moreover, strong and irregular precipitation events may damage the vegetation and wash fertile soil into rivers. Many recent publications have attempted to predict the impact of an enhanced greenhouse effect upon regional water resources in the twenty-first century (e.g., [21, 24, 25, 26]). If the first generation climate models had a too coarse spatial resolution to reproduce the regional characteristics of the hydrological budget, the most recent Earth climate models combine atmosphere, ocean and land 
surface interactions, in order to evaluate the water resources components. The studies of Arnell and King [27] and Jones et al. [28] compare the impact on water resources with a calculated increase in demand, based on recent estimates of national population growth rates [16]. The results of those studies show that, in addition to the increase in number and intensity of extreme events (such as droughts and floods), the bigger climate variability will likely have direct and indirect impacts on the economic and social development. In fact, climate change, differently from other drivers, determines how much water there is in the Earth system, while other drivers, being demand-side drivers, influence how much water is required. In other words, climate change directly affects the hydrologic cycle by altering the quantity (and quality) of water resources, both for ecosystem and human activities [29].

\section{Conclusions}

One of the most urgent challenges facing the world today is ensuring an adequate supply and quality of water in light of both burgeoning human and ecosystem needs and climate variability and change. Variations in evaporation and precipitation patterns due to climate and land use changes, as well as increasing water usage to meet human needs, are fundamentally changing the availability, quality, and timing of water across the globe. Despite its importance to life on Earth, there are major gaps in our basic scientific knowledge of the water cycle, including the impact of a changing climate and human activity on water availability and quality. How can we protect ecosystems and better manage and predict water availability for future generations given alterations to the water cycle caused by climate variability and change and human activities?

Climate change poses a further threat. In history, humans have learnt how to manage water resources, by practically finding solutions to the naturally occurring variability. Now, the threat of climate change concurs to increase the natural variability, introducing greater uncertainties in the quantity and quality of long term water supplies and posing problems for their sustainability.

In order to address this question, a holistic approach is needed, involving the predictive understanding of the complex water cycle and water resource processes, the feedbacks associated with the water system, and the vulnerability and resilience of water systems to climate and anthropogenic change. There have been few attempts to study an entire water system with an integrative, systems science approach or even study similar aspects of different water systems in a comparative sense that will develop such a framework.

In summary, the emerging key messages are as follows. First: there is evidence that the global climate is changing, and the main impacts of climate change on humans and the environment occur through water. Second: climate change is a fundamental driver of change in water resources and an additional stressor through its effects on other external drivers. Third: policies and practices for mitigating climate change or adapting to it can have impacts on water resources, and the way we manage water can affect the climate.

\section{References}

1. Gleick, P.H. Water resources. In Encyclopedia of Climate and Weather; Schneider, S.H. Ed.; Oxford University Press: New York, USA, 1996; Vol. 2, pp. 817-823.

2. Earth's water distribution. United States Geological Survey, 2009. Available online: http://ga.water.usgs.gov/edu/waterdistribution.html (accessed on 15 May 2009). 
3. Water Facts \& Trends. WBCSD, 2009. Available online: http://www.wbcsd.org/includes/getTarget.asp?type=d\&id=MTYyNTA (accessed on 12 March 2009).

4. Postel, S. Last Oasis: Facing Water Scarcity, 2nd ed.; W.W. Norton \& Co.: New York, NY, USA, 1997.

5. Hinrichsen, D. 1998. Feeding a future world. People and the Planet 1998, 7, 6-9.

6. Pratt, B. Agricultural Statistics 1995-96, 1st ed.; Government Printing Office: Washington, DC, USA, 1996.

7. Gleick, P.H. Water in Crisis; Oxford University Press: New York, NY, USA, 1993.

8. Comprehensive Assessment of Water Management in Agriculture. Water for Food, Water for Life: A Comprehensive Assessment of Water Management in Agriculture; UK International Water Management Institute: London, UK, 2007.

9. World Health Organization. Our Planet, our Health: Report of the WHO Commission on Health and Environment; World Health Organization: Geneva, Switzerland, 1992.

10. Environment Protection Agency. Quality of Our Nation's Water 1994; U.S. Environmental Protection Agency: Washington, DC, USA, 1994. Available online: http://www.epa.gov/305b/94report/index.html (accessed on 12 May 2009).

11. World Research Institute. World Resources 1991-92; World Resources Institute: Washington, DC, USA, 1991.

12. Nash, L. Water quality and health. In Water in Crisis: A Guide to the World's Fresh Water Resources; Gleick, P., Ed.; Oxford University Press: New York, NY, USA, 1993; pp. 25-39.

13. World Water Assessment Programme. The United Nations World Water Development Report 1: Water for People, Water for Life; United Nations Educational, Scientific and Cultural Organization (UNESCO), and Berghahn Books, 2003. Available online: http://www.unesco.org/water/wwap/wwdr/wwdr1/table_contents/index.shtml (accessed on 7 June 2011).

14. United Nations Environment Programme. Freshwater Pollution; Global Environment Monitoring System Library n. 6; United Nations Environment Programme: Nairobi, Kenya, 1991.

15. Jones, J.A.A. Global Hydrology: Processes, Resources and Environmental Management; Addison Wesley Longman: Harlow, UK, 1997.

16. World Meteorological Organization. Comprehensive Assessment of the Freshwater Resources of the World; WMO: Geneva, Switzerland, 1997.

17. IPCC. Climate Change 2007-Sinthesis Report; Pachauri, R.K., Reisinger, A., Eds.; IPCC: Geneva, Switzerland, 2007.

18. IPCC (Intergovernmental Panel on Climate Change). Technical Paper on Climate Change and Water; IPCC XXVIII/Doc.13; Intergovernmental Panel on Climate Change: Geneva, Switzerland, 2008. Available online: http://www.ipcc.ch/meetings/session28/doc13.pdf (accessed on 7 June 2011). 
19. Jones, D.A. Seasonal climate summary southern hemisphere (autumn 1995-96): a return to near-normal conditions in the tropical Pacific. Aust. Met. Mag. 1996, 45, 203-211.

20. Pilling, C.; Jones, J.A.A. High resolution equilibrium and transient climate change scenario implications for British runoff. Hydrolog. Process. 1999, 13, 2877-2895.

21. Meehl, G. A., C. Covey, T. Delworth, M. Latif, B. McAvaney, J. F. B. Mitchell, R. J. Stouffer, and K. E. Taylor, 2007: The WCRP CMIP3 multi-model dataset: A new era in climate change research,Bulletin of the American Meteorological Society, 88, 1383-1394.

22. WCRP Coupled Model Intercomparison Project - Phase 5: Special Issue of the CLIVAR Exchanges Newsletter, No. 56, 15, No. 2.

23. Arnell, N.W.; Reynard, N.S. Impact of Climate Change on River Flow Regimes in the United Kingdom; Report to Department of the Environment; Institute of Hydrology: Wallingford, UK, 1993.

24. Arnell, N.W. Global Warming, River Flows and Water Resources; Wiley: Chichester, UK and New York, NY, USA, 1996.

25. IPCC, 1996. Climate Change 1995-The Science of Climate Change; Houghton, J.T., Jenkins, G.J., Ephraums, J.J., Eds.; Cambridge University Press: Cambridge, UK.

26. Jones, M.B.; Jongen, M.; Doyle, T. Effects of elevated carbon dioxide concentrations on agricultural grassland production. Agr. Forest Meteorol. 1996, 79, 243-252.

27. Arnell, N.W.; King, R. The impact of climate change on water resources. In Climate Change and its Impacts: A Global Perspective; Department of the Environment, Transport and the Regions/The Meteorological Office, Meteorological Office Graphics Studio: Bradenell, UK, 1997; pp. 10-11.

28. Jones, J.A.A.; Mountain, N.C.; Pilling C.G.; Holt, C.P. Implications of climate change for river regimes in Wales-A comparison of scenarios and models. In Water in Celtic Countries: Quantity, Quality and Climatic Variability; Lobo Ferreira, J.-P., Vieira, J.M.P., Eds.; Publication 310; International Association of Hydrological Sciences: Wallingford, UK, 2007; pp. 71-77.

29. C. Cassardo and J. A. A. Jones (2011): Editorial: Managing Water in a Changing World, Water, 3(2), 618-628; doi:10.3390/w3020618 